\section{Biological contaminants in the River Nun and environmental ethics of riverside communities in the Niger Delta: The case of Amassoma, Bayelsa, Nigeria}

\author{
Contaminantes biológicosno Rio Nun e ética ambiental das comunidades \\ ribeirinhas no Delta do Níger: $O$ caso do Amassoma, Bayelsa, Nigéria
}

Ifeanyichukwu Clinton Ezekwe ${ }^{[a]}$, Ahamefula Sunday Ezekwe ${ }^{[b]}$, Path Oweikeye Endoro ${ }^{[c]}$

\begin{abstract}
The river Nun at Amassoma community in Bayelsa, Nigeria is a major source of domestic water and sink. Riverside communities in this part of the world believe that rivers have the assimilative capacity to purify themselves inexorably from human wastes hence bathing and defecation takes place on the town side of rivers while domestic water is collected mid-stream and at the opposite banks of rivers. Based on the premise that the community perception influences usage of environmental resources, this study aims to examined the veracity of this perception and the impact of this attitude on the quality of the Nun River by examining the presence of selected biological contaminants in the river and the potential health hazards posed by these biological communities in water. Nine water samples were selected from three zones along the river (upstream, town and downstream) and subjected to microbial analysis for Escherichia coli, Pseudomonas, Coliform and Salmonella species and compared with WHO-FEPA standards. This study found concentration of biological communities above standards and a higher concentration of contaminants in the mid-stream and town side of the river bank. Basic water treatment and sanitation; environmental education and an alternative waste management system is recommended to safeguard the lives of the growing population in riverside communities.
\end{abstract}

Keywords: Biological contaminants. Riverside communities. Urban ecology. Water quality. River assimilative capacity.

\section{Resumo}

0 rio Num é uma importante fonte de água para uso doméstico da comunidade Amassoma em Bayelsa, Nigéria. As comunidades ribeirinhas dessa região acreditam que os rios têm a capacidade de assimilar e de purificar-se de resíduos humanos. Dessa forma, tanto o banho quanto a defecação ocorrem na margem do rio voltado para a cidade. Já a coleta de água para uso doméstico é realizada no centro e na margem oposta. Partindo da premissa de que a percepção da comunidade influencia diretamente o uso dos recursos ambientais, objetivou-se examinar a veracidade dessa percepção e seu impacto sobre a qualidade do rio Nun. Para tal, foram avaliados a presença de contaminantes biológicos no rio e os riscos potenciais para a saúde decorrentes de tais comunidades biológicas. Nove amostras de água foram selecionadas a partir de três zonas ao longo do rio (a montante, a jusante e na cidade); essas amostras foram submetidas à análise microbiana para Escherichia coli, Pseudomonas, coliformes e espécies de Salmonella e foram comparados com padrões WHO-FEPA. Este estudo encontrou concentrações acima dos padrões de referência, além de maior concentração de contaminantes no fluxo médio próximo à cidade. 0 tratamento da água bem como o saneamento básico, educação ambiental e um sistema alternativo de gerenciamento de resíduos são recomendados para salvaguardar a vida das crescentes populações ribeirinhas da região.

Palavras-chave: Contaminantes biológicos. Comunidades ribeirinhas. Ecologia urbana. Qualidade da água. Capacidade assimilativa do rios.

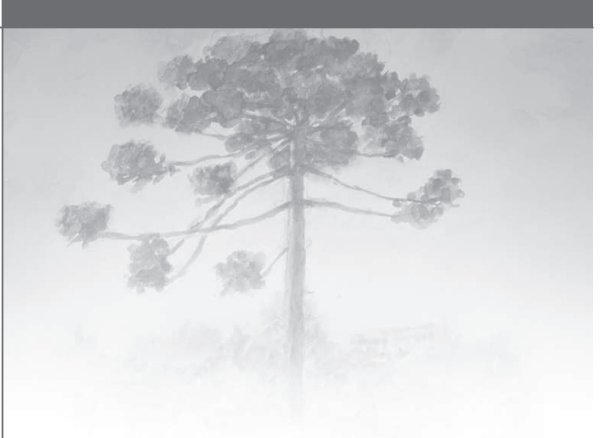

${ }^{[a]}$ Environmental Hydrologist and Lecturer at the Department of Geography and Environmental Management, University of Port Harcourt, Port Harcourt - Nigeria, e- mail: clidnelson@yahoo.com

${ }^{[b]}$ Medical Practitioner and post-graduate researcher (Department of Clinical Biochemistry) at the Abia State University, Uturu - Nigeria, e-mail dr_roydavidson@yahoo.co.uk

${ }^{[c]}$ Graduate student of the Niger Delta University and Environmental activist with the Ijaw Youth Council, Ekpan Warri - Nigeria, e-mail: endoweipath@gmail.com 


\section{Introduction}

Ethics refers to our character which presupposes our ability to distinguish between what is wrong or right. This defines beliefs and value systems which ultimately defines the propensity of a person or society. Environmental ethics which are the bedrock of environmental perception therefore are those ethical values, human reasoning and knowledge of nature which endeavor to forge a pattern of "right" conduct towards the environment (Asthana \& Asthana, 2006).

In the riverine communities of the Niger Delta area of Nigeria, the river occupies a socio-religious, instrumental and intrinsic value to inhabitants. The river is thus an abode of the oft-revered water goddess, a source of water and fish and a sink for human waste. Traditionally, the harsh realities of hitherto unavailability or the opportunity cost of alternative sources of human excreta management has made the river a ready and generally acceptable sink for this kind of waste. This attitude is an expressed form of primary anthropocentrism (Brennan, 2008) borne out of a firm believe that nature is subservient to man and even the revered goddess must serve the purpose of man's survival. If not, how does man desecrate with faecal matter the abode of a revered deity? Also it is believed that the environment (in this case the river) has an unlimited capacity to "clean" itself and the concept of "dirty no day kill African man' which is an innuendo to a perceived high resistance of the typical African to germs and diseases is a major expression of the superiority of man to his environment. This type of philosophy, whether rightly or wrongly formulated, has established the use of the river as a sink. The power of this perception can be seen in most communities as water from untreated river sources are used for domestic purposes.

An innate understanding also of the place of contaminants in the food chain by communities in pre-modern times has informed the establishment of local laws emphasizing basic source protection of water supply sources and the idea of collecting water upstream or midstream from the riverside of communities. However, the efficacy of this perception in sustaining public health and environmental resources in the presence of decreasing living standards, increasing population pressures, urbanization and spiraling environmental pollution in the region remains to be seen.

The use of water bodies as sinks for industrial and mining waste is a major water quality problem all over the world (Longe \& Omole, 2008), and it is fatalistic to believe that water bodies have an unlimited capacity for waste assimilation. The natural purification of polluted rivers is never fast and heavily polluted water may traverse long distances in days before a significant degree of purification is achieved (Chima, Nwaugo \& Ezekwe, 2010). A century ago, the main contamination problems worldwide were faecal and organic pollution from untreated human waste and industrial by-products. These pollution sources have been greatly reduced in most industrialized countries. Meanwhile in most developing countries, traditional pollution sources and new pollutants like pesticides have combined to heavily degrade water quality near urban centers and intensive agricultural areas (Holmes, Newman, Chadd, Rouen, Saint \& Dawson, 2009).

The World Health Organization (2006) estimated that $17 \%$ of the global population lacked access to improved water sources, $45 \%$ lacked access to improved sanitation; $90 \%$ of the children under 5 years old die annually from diarrhea, which is attributed to poor water supply and inadequate sanitation. In developing countries, an estimated $90 \%$ of untreated waste water is discharged directly into river and streams polluting river and lakes to levels that make them unfit even for industrial uses (Asonye, Okolie, Okenwa \& Iwuanyanwu, 2007).

The effects of this contamination without any action result in eutrophication and other related ecological problems. Important also is that most pollution in rivers that abut urban areas occur in the downstream segment of these population centers (Clabby, Lucey \& McGarrigle, 2006) and pollution levels tends to be more intense in smaller rivers where dilution is less effective. The Bogota and Lapaz rivers are perfect examples of rivers that have become life-less as a result of man's activities on their banks and watersheds (EPA, 2006).

One of the most frequent types of contamination in rural communities is faecal pollution from different sources, most frequently livestock and inadequate on-site human waste disposal systems (Fjellheim \& Raddum, 2007). The size and shape of pathogenic microorganisms, their surface density properties and biological activities set them apart from other contaminants that are transported in surface and subsurface water environments (Lingireddy, 2002) and concentrations of micro-biological contamination indicator organism observed in ground and 
surface water are a function of the contamination source active at that moment (Hynes, 2004).

Since the largest number of faecal coliform and faecal streptococci is always present in manure (Walley \& Hawkes, 2003) then the presence of either of these microbe in a surface water sample is strong evidence of faecal contamination. Microbiological contamination, is therefore dispersed, sporadically and influenced by a range of interacting environmental factors such as the watersheds physical characteristics, climatic conditions and the activities of man like waste disposal and agricultural management practices.

The most serious water pollutions in terms of human health worldwide are pathogenic organisms such as Pseudomonas and Salmonella. The most important water-related diseases include typhoid fever, cholera, bacterial and amoebic dysentery, hepatitis, malaria, yellow fever, filariosis and schistosomiasis. At least 25 million deaths recorded each year mostly in third world countries are from these diseases and nearly two-third of these mortalities are children under 5 years old (Cummingham, 2005).

\section{Biological communities in freshwater}

The biological characteristics of a water body refer to the variety of living organisms that can be found in water. These include microscopic viruses, bacteria and protozoans; as well as phytoplankton (microscopic algea), zooplankton (tiny water animals) insects, worms, micro and macrophytes and fishes. Of interest to human health however are the pathogenic species. A wide variety of pathogens may be found in the excrement from human as well as from other animals. Most human pathogens can be classified as viruses, protozoan helminthes (intestinal worms) or bacteria. Both raw sanitary sewage and land runoff contain pathogenic organisms, and virtually every sizeable body of water contains some pathogens. However the type, concentration and distribution of pathogens in a water body are acutely important to environmental health (British Columbia Groundwater Assoc., 2007). Approximately 20\% of the reported outbreaks and illness associated with water have been attributed to bacterial pathogens belonging to the genera Salmonella, Pseudomonas and Shigella (Geldreich, 1972).
Salmonella is a gram-negative facultative rod-shaped bacterium in the same proteobacterial family as Escherichia coli, the family Enterobacteriaceae, trivially known as "enteric" Bacteria. Salmonella is nearly studied as E. coli from a structure biochemical and molecular point of view, and as poorly understood as E. coli from an ecological point of view. Salmonella lives in the intestinal tracts of warm and cold blooded animals with some species ubiquitous and others specially adapted to particular hosts. In humans, salmonella causes salmonellosis; an enteric fever (typhoid), resulting from bacterial invasion of the bloodstream and acute gastroenteritis (Toner et al., 2005; History of water filters, 2010).

Escherichia coli are gram-negative bacteria that can survive in an environment with or without air (facultative anaerobes) and depending on the environment, may or may not produce thin hair-like structures (flagella or pilli) that allow the bacteria to move and to attach to human cells. The species is found in the intestine of all warm-blood animals, including humans. In fact, human faeces may consist of as much as $50-52 \%$ of $E$. coli. Certain serotypes of E. coli referred to as entero-pathogenic that they cause diarrhea. Indeed, children are particularly susceptible to this form of diarrhea (Lingireddy, 2002; British Columbia Groundwater Assoc., 2007; History of water filters, 2010).

The presence of coliform bacteria in water does not necessarily indicate water contamination by fecal waste; however the presence of fecal coliform in water may indicate recent contamination by human sewage or animal dropping which could contain other bacteria, viruses, or diseases causing organisms. This is why coliform bacteria are considered "indicator organism". Their presence warns of the potential presence of disease causing organisms and should alert the people responsible to take precautionary action (Lingireddy, 2002; British Columbia Groundwater Assoc., 2007; History of water filters, 2010).

The Pseudomonas group is another important water-borne bacterium. They are a genus of gammaproteobacteria, belonging to the family Pseudomonadaceae containing 191 validly described species (Euzeby, 1997). It includes strains formerly classified in the genera Chryseomonas and Flavimonas (Anzai, Kim, Park, Wakabayashi \& Oyaizu, 2000). Common Pseudomonas include Aeruginosa sp., Fluorescens sp., Putida sp. or Stutzeri sp. An $8 \%$ rise in bactraemiasis from Pseudonomas spp., was reported 
in England, Wales and Northern Ireland between 2006 and 2008. In 2010, 90\% of Pseudomonas spp. isolates from bacteremia were identified to species level $(3,432$ reports), with $93 \%$ of these identified as P. aeruginosa.

P. aeruginosa is a gram-negative bacterium commonly found in soil and ground water. It rarely affects healthy people and most community-acquired infections are associated with prolonged contact with contaminated water (HPA, 2011). Other water borne pathogens include Vibrio cholera which causes an extreme diarrheal disease and Giaolia lamblia which causes giardiasis various viruses and worms which cause varied intestinal and skin diseases.

The river Nun at Amassoma community in Bayelsa, Nigeria is a major source of domestic water and sink. Riverside communities in this part of the world believe that rivers have the assimilative capacity to purify themselves inexorably from human wastes hence bathing and defecation takes place on the town side of rivers while domestic water is collected mid-stream and at the opposite banks of rivers. Based on the premise that the community perception influences usage of environmental resources, this study aims to examine the veracity of this perception and the impact of this attitude on the quality of the Nun River by examining the presence of selected biological contaminants in the river and the potential health hazards posed by these biological communities in water.

\section{Materials and methods}

\section{Study area}

Amassoma town is host to the Niger Delta University since 1996. The town has a land area of less than $30 \mathrm{~km}^{2}$ and is situated about $40 \mathrm{~km}$ West of Yenagoa, the Bayelsa State capital on the banks of the River Nun and in the heart of the rainforest of South-south Nigeria (Figure 1). The town is located within 006 04' 30" and 006 07, 30" E longitude and 04 56' 42" and 04 59' 06"N latitude. Before the establishment of the university, the town was a typical riverside community whose economic activities included fish trading, local fishing, farming and a bit of lumbering. The town is currently experiencing a lot of change in population characteristics due to the influx of people as a result of the establishment of the university. Population currently is about 150,000 inhabitants and extreme pressures on infrastructural and natural resources is the order of the day as the university was established without commensurate urban planning and the establishment of infrastructures capable of servicing a university town.

Acute shortages in various amenities including housing and sanitation, waste disposal system, non-availability of potable water supply and power system are major challenges in this town. This situation therefore reinforces the accepted ethos where the river as the most readily source of water becomes a sink for domestic and human waste. Early morning baths and defecation at the river bank is a common sight and waste pipes from flush toilet systems channeled directly into the river and semi floating latrines can be seen dotting the rivers cape of the banks of the Nun. It is feared that waste discharges may have exceeded the river's capacity to process raw waste, and because people rely heavily on surface water from streams and rivers for fishing, recreation, washing and drinking water, the risk to human health is great.

\section{Sample collection}

Water sampling was designed in such a way that the effect of the Amassoma town on the biological quality of the River Nun could be measured. Sampling station were selected $2 \mathrm{~km}$ upstream and downstream of Amassoma before Turu-ebeni and Otuan villages respectively (Figure 2). Samples were also collected at the NDU Jetty in Amassoma town (middle zone). At each sampling station, three samples were collected; at the town side banks, the mid dle of the river and in the opposite bank of the river. This is to help in measuring the chief effect of human activities on biological communities, the effect of dilution and to assess the efficacy of the local belief that water from the middle and opposite banks of rivers from riverine communities are safe for domestic use. Samples were collected in pre-labelled $1 \mathrm{~L}$ white plastic sterile and analyzed within four hours. Samples were stored in coolers below $4{ }^{\circ} \mathrm{C}$ to en hance the survival of micro-organisms and avoid contamination from ambient environment

\section{Laboratory analysis}

Samples were serially diluted, surface plated in duplicate in appropriate media before microbial analysis. 


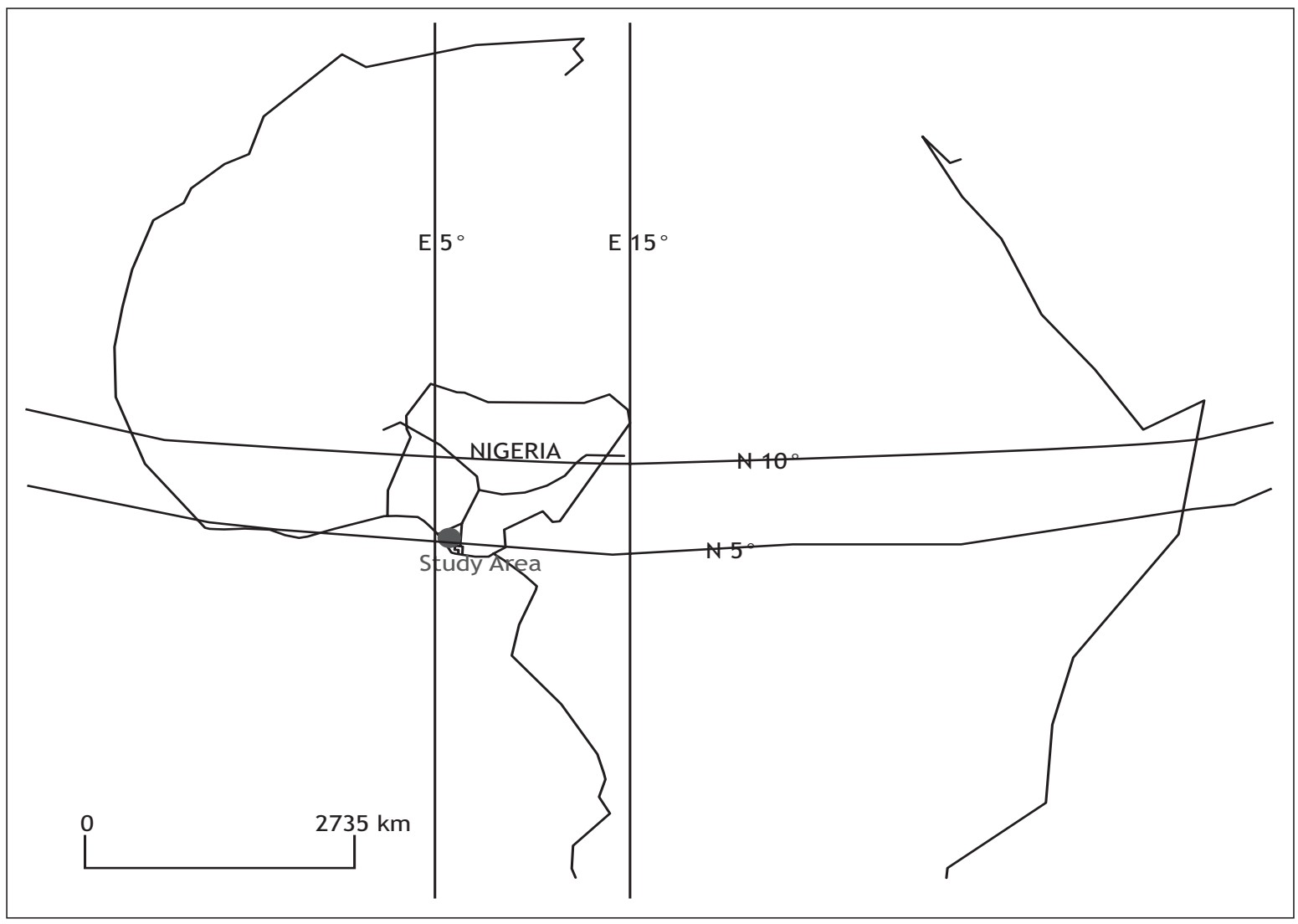

Figure 1 - Location of the study area Source: Research data.

Microbiological analyses of water samples were performed using standard methods (APHA, AWWA, WEF, 1998). Total coliform, E. coli, Salmonella and supplementary microorganism Peudonomas aeruginosa were enumerated by the membrane filtration technique, according to standard and the results expressed as colony forming units (cfu) per $100 \mathrm{~mL}$. The selective and recovery media used and incubation conditions were the following: Nutrient agar for total coliform, violet red bile lactose (VRBL) agar for presumptive $E$. coli counts, agar for Salmonella and centrimide agar for Pseudonomas aeruginosa counts. Nutrient agar plates were incubated at $28+-1^{\circ} \mathrm{C}$ and counted after 24 hours and 48 hours. All other plates were incubated at $37^{\circ} \mathrm{C}$ and counted after 48 hours. All other plates were incubated at $37^{\circ} \mathrm{C}$ and counted after 48 hours.

All the media used were weighed out and prepared according to the manufacture's specification, with respect to the given instructions and directions. A serial dilution method was used for total viable count and the presumptive test for coliforms. The sterility of each batch of test medium was confirmed by incubating one or two uninoculated tubes or plates along with the inoculated tests. The uninoculated tubes or plates were always examined to show no evidence of bacterial growth. Any uninoculated tube or plate that showed evidence of bacterial growth was discarded. The pure cultures of the bacterial isolates were subjected to various morphological and biochemical characterization tests to determine the identity of the bacteria isolates with reference to Bergey's Manual of Determinative Bacteriology (Buchanan \& Gibbons, 1974). Results were also subjected to pearson's correlation statistic using the SPSS software (SPSS INC., 1983).

\section{Results and discussion}




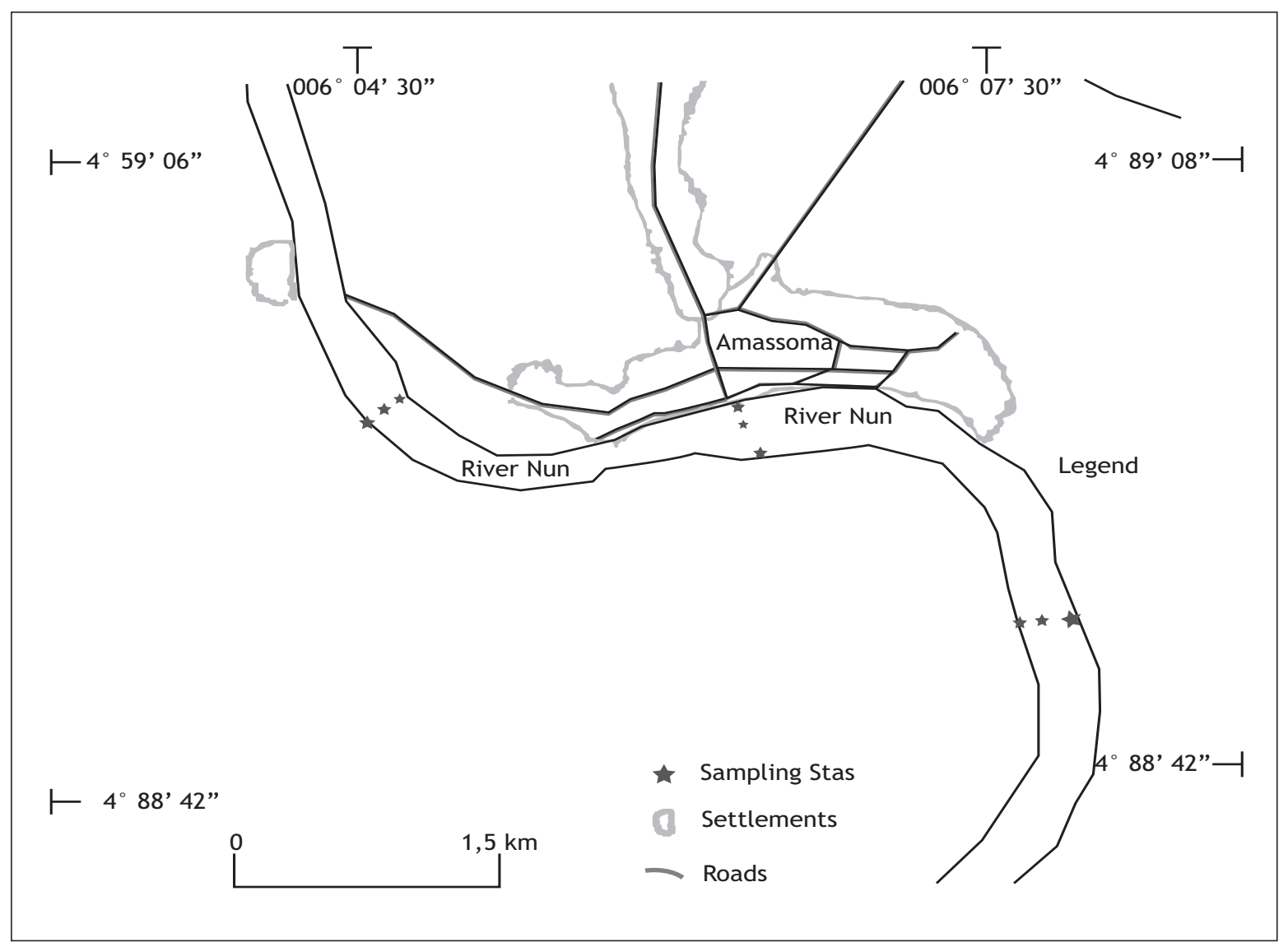

Figure 2 - Points of water sampling

Source: Research data.

From the results, the River Nun quality around Amassoma town does not meet the WHO-FEPA standards for domestic water use in all the micro-organisms tested (Table 1). The colony forming units for the presumptive total coliform count of the water samples ranges from 9 to $49 \mathrm{CFU} / 100 \mathrm{~mL}$ indicating gross contamination. The river bank at Amassoma town has the highest concentration of coliform bacteria with a count of $49 \mathrm{CFU} / 100 \mathrm{~mL}$. E. coli species were present in almost all the samples in the study area except sample DSL3. However, the colony count ranges from 1 to 7, with sites MSL1 and DSL1 bearing the highest count of 6 and 7 colonies respectively. Pseudomonas species were present in all samples except USL 3 and DSL 3; colony count ranged between 1 and 4. Salmonella species had colony range of between 1 and 5 and was present in all the sites apart from USL 3 and DSL 3.

Continuous human and material waste discharges into the Nun River in this area explains this explain the high values of indicator species (Table 1). The widespread occurrence of pathogenic species in the Nun River at Amassoma especially the widespread and high concentration of indicator coliform species is a pointer to a high level of biological pollution and this has been intensified by growing economic activities and population pressures in Amassoma town as total number of tested colonies increased from 57 upstream to 118 in the town and 97 in the downstream sections of the river (Table 1).

The assimilative capacity for the Nun River under urbanized conditions as typical in Amassoma town is therefore about $17.8 \% / \mathrm{km}$; an index obtained from a percentage of the difference between total colony count in the town and that at a distance two kilometers from the edge of the town. Level of pollution between the town side banks, midstream and opposite banks has almost a ratio of 1.5:1:0.5. This somewhat conforms to the belief of the local people that the 
Table 1 - Result of analysis of contaminants

\begin{tabular}{|c|c|c|c|c|c|c|c|c|c|c|c|c|c|}
\hline Parameter & Media & $\begin{array}{l}\text { WHO/ } \\
\text { FEPA }\end{array}$ & USL1 & USL2 & USL3 & MSL1 & MSL2 & MSL3 & DSL1 & DSL2 & DSL3 & Total & $\begin{array}{l}\text { Culture } \\
\text { character }\end{array}$ \\
\hline Coliform & $\begin{array}{l}\text { Nutrient Agar } \\
\text { (NA) }\end{array}$ & $\begin{array}{l}0 \mathrm{in} \\
100 \mathrm{ml}\end{array}$ & 9 & 20 & 14 & 49 & 28 & 16 & 45 & 21 & 10 & 221 & varying \\
\hline E. coli & $\begin{array}{l}\text { Violet Red } \\
\text { Bile } \\
\text { (VRB) }\end{array}$ & $\begin{array}{l}0 \mathrm{in} \\
100 \mathrm{ml}\end{array}$ & 2 & 3 & 1 & 7 & 3 & 3 & 3 & 6 & 0 & 28 & $\begin{array}{l}\text { Spindle } \\
\text { shape }\end{array}$ \\
\hline $\begin{array}{l}\text { Pseudomo- } \\
\text { nas }\end{array}$ & $\begin{array}{l}\text { CentrimideAgar } \\
\text { (CA) }\end{array}$ & $\begin{array}{l}0 \mathrm{in} \\
100 \mathrm{ml}\end{array}$ & 1 & 4 & 0 & 3 & 1 & 1 & 2 & 4 & 0 & 16 & $\begin{array}{l}\text { Flat green } \\
\text { pigment }\end{array}$ \\
\hline Salmonella & $\begin{array}{l}\text { Salmonella } \\
\text { Agar } \\
\text { (SA) }\end{array}$ & $\begin{array}{l}\text { No } \\
\text { guide } \\
\text { line }\end{array}$ & 1 & 2 & 0 & 3 & 2 & 2 & 1 & 5 & 0 & 16 & $\begin{array}{l}\text { Circular } \\
\text { black centre } \\
\text { with clear } \\
\text { edge }\end{array}$ \\
\hline Total & & & 13 & 29 & 15 & 62 & 34 & 22 & 51 & 36 & 10 & & \\
\hline
\end{tabular}

Legend: N/B: USL = Upstream sample location; MSL = Middle zone sample location; DSL = Downstream sample location.

Source: Research data.

Note: Results are compared with the WHO-FEPA (2004) standard for biological contaminants in water.

middle and opposite sections of the river are less polluted (not unpolluted) than the town side banks of riverside communities. This emphasizes the contribution of human activities to water pollution in the study area.

To establish the relationship between the parameters tested in the three sampling stations, the Pearson coefficient test was applied. The indicator species showed significant correlation with the pathogenic species both at the $p>0.01$ and $p>0.05$, respectively. There is a statistically significant difference $(p>0.05)$ between water samples at the opposite bank of the river and the ones collected from the town side and the middle points of the river. There is also a statistically significant difference $(p>0.05)$ between the upstream water samples and downstream from sample station 1 . This shows that human activities are contributing immensely to river contamination. Results also indicate that Salmonella and Peudonomas species tend to thrive better in the middle sections of the river. This might be an indication of a higher resilience and survival ability than other biological communities.

It can be safely concluded that the environmental ethos which encourages the use of rivers as sinks for human wastes is fatalistic in the light of increasing population pressures on our communities; a concomitant increase in waste and pollutant generation and a decreasing capacity of rivers to assimilate excess bioloads. Earlier studies (APHA, AWWA, WEF, 1998) of faecal coliforms in the bank and midstream of the Amassoma River revealed higher coliform counts and an increasing trend in water related diseases between 2005 and 2007. The difference in microbial counts may have been affected by season of sampling as the stated study was conducted in June $2007 \mathrm{du}$ ring the wet season while this study was conducted in February 2011at the peak of the dry season. There may also be a tendency towards decreasing use of the river as a toilet as the university has commissioned some hostels for students and some level of modern housing is being introduced by commercial ventures.

Continued use of the Nun River as a sink for especially faecal waste is an expression of a form of traditional anthropocentrism (Brennan, 2008); and it has become very obvious from this study that it is an environmentally unsustainable practice. We hereby recommend that serious environmental and health education at all levels of society especially with women and children be carried out in riverine communities in the Niger Delta of Nigeria. Riverine communities also require great attention from both governmental and non-governmental agencies as urgent attention needs to be paid to the provision of cheap and sustainable basic sanitation systems. Also individuals in the community need to at least boil their water or treat water meant for domestic usage with cheap harmless chemicals like the water guard before using them. 
State and local governments should also examine ways of providing sustainable low cost sewage treatment technologies or plants for the management of wastes before discharge, in order to ensure a drastic reduction in the pollution of surface water that will enhance good health conditions of the inhabitants or the locals. It is apparent that continues development of policies and programs geared towards minimizing the risk of contracting waterborne diseases should be supported to improve optimal health service delivery for the population.

\section{Acknowledgements}

We are grateful to the anonymous reviewers whose advice and suggestions enhanced the quality of this presentation.

\section{References}

Anzai, Y., Kim, H., Park, J. Y., \& Wakabayashi, H. (2000). Phylogenetic affiliation of the pseudomonads based on 16S rRNA sequence. International Journal of Systematic and Evolutionary Microbiology, 50(4), 1563-1589. doi:10.1099/00207713-50-4-1563.

APHA, AWWA, WEF. (1998). Standard Methods for the Examination of Water and Wastewaters. (20 ed.). Washington, DC: American Public Health Association.

Asonye, C. C., Okolie, N. P., Okenwa, E. E., \& Iwuanyanwu, U. G. (2007). Some physico-chemical characteristics and heavy metal profiles of Nigerian rivers, streams and waterways. African Journal of Biotechnology, 6(5), 617-624.

Asthana, D. K., \& Asthana, M. (2006). A Textbook of Environmental Studies. India: S. Chand.

Brennan A. (2008). Environmental Ethics. The Stanford Encyclopedia of Philosophy. Recovered on January 25, 2013, frrom http://plato.stanford.edu/entries/ ethics-environmental/

British Columbia Groundwater Assoc. (2007). Water Stewardship Information Series, Total, Fecal \& E. coli Bacteria in Groundwater. Recovered on January 25, 2013, from http://www.env.gov.bc.ca/wsd/plan_protect_sustain/groundwater/library/ground_fact_ sheets/pdfs/coliform\%28020715\%29_fin2.pdf
Buchanan, R. E., Gibbons, N. E. (1974). Bergey's Manual of Determinative Bacteriology (8th ed.). Baltimore: The Williams and Wilkins Company.

Centre for Disease Control and Prevention. (2007). National Centre for Prevention Services, Division of Oral Health. Water supply statistics. Atlanta: Centres for Disease Control and Prevention.

Chima, G. N., Nwaugo, V. O., \& Ezekwe I. C. (2010). Impacts of Rock Quarrying on Akwukwuo Tributary of the Ivo River in Ishiagu Ebonyi State, Nigeria. Journal of Applied Environmental. Sciences, 6(2), 68-73

Clabby, K. J., Lucey, J., \& McGarrigle, M. L. (2006). Interim report on the biological survey of river quality. Results of the 2004 investigations. Environmental Protection Agency, Ireland.

Cummingham, W. P. (2005). Environmental Science: A global concern. (8. ed.). New York: McGraw Hill.

EPA (2006). Water Framework Directive Monitoring Programme. Version 1 2006. Prepared to meet the requirements of the EU Water Framework Directive (2000/60/EC) and National Regulations implementing the Water Framework Directive (S.I. n. 722 of 2003) and National Regulations implementing the Nitrates Directive (S.I n.. 788 of 2005). Environmental Protection Agency, Ireland.

Euzeby, J. P. (1997). List of bacterial names with standing in nomenclature: A folder available on the Internet. International Journal of Systematic Bacteriology, 47(2), 590-592. doi: 10.1099/00207713-47-2-590.

Fjellheim, A., \& Raddum, G. G. (2007). Recovery of acid sensitive species of Ephemeroptera, Plecoptera and Tricoptera after liming in River Audna after liming. Environmental Pollution, 78(1-3), 173-178.

Fratamico, P. M., \& Smith, J. L. 2005. Escherichia coli. In Foodborne Infections and Intoxications. D. O. Cliver and H. Reimann (8. ed., pp. 205-258). New York: Academic Press.

Geldreich, E. E. (1972). Water Borne Pathogens. New York: Second Edition. Geldreich, E. E. (1972). Water-borne pathogens. In R. Mitchell (Ed.). Water pollution

Microbiology. (pp. 207-241). New York: Wiley-Interscience. 
HPA, Health Protection Agency, UK, (2011). Pseudomonas spp. and Stenotrophomonas maltophilia bacteraemia in England, Wales, and Northern Ireland, 2006 to 2010. Recovered on January 25, 2013, from http://www.hpa. org.uk/web/HPAwebFile/HPAweb_C/1309968922480

History of water filters (2010). Contaminates Resulting from Biological matter in water. Recovered on January 25, 2013, from www.historyofwaterfilters.com

Holmes, N. T. H., Newman, J. R., Chadd, S., Rouen, K.J., Saint, L., \& Dawson, F. H. (2009). Mean Trophic Rank: A User's Manual. $R \& D$ Technical Report E38. UK Environment Agency. Recovered on January 25, 2013, from http://www.epa.ie/ wfdstatus/rivers/rw_mtr_methods_manual.pdf
Hynes, H. B. N. (2004). A key to the adults and nymphs of British stoneflies (Plecoptera). Freshwater Biological Association, Scientific Publication, 17. Recovered on January 25, 2013, from: http://www.amazon.co.uk/ Adults-Nymphs-British-Stoneflies-Plecoptera/ dp/0900386282

Lingireddy, S. (Ed.). (2002). Control of Microorganisms in drinking water. Reston, Virgina: American society of Civil Engineers.

Longe, E. O., \& Omole, D. O. (2008). Analysis of Pollution Status of River Illo, Ota, Nigeria. The Environmentalist, 28, 4.

SPSS INC. (1983). SPSS for Windows 10. Recovered on January 25, 2013, from http://www.spssscience.com

Toner, P., Bowman, J., Clabby, K., Lucey J., McGarrigle, M., Concannon, C., etal. (2005). Water Qualityin Ireland 20012003. Ireland: Environmental Protection Agency.

Walley, W. J., \& Hawkes, H. A. (2003). A computer-based reappraisal of Biological Monitoring Working Party scores using data from the 1990 River Quality Survey of England and Wales.

World Health Organization, [WHO]. (2004). Guidelines for drinking water quality. 3. ed. Geneva: World health organization. 